\title{
Central Asian 'Characteristics' on China's New Silk Road: The Role of Landscape and the Politics of Infrastructure
}

\author{
Troy Sternberg *, Ariell Ahearn and Fiona McConnell
}

School of Geography, University of Oxford, Oxford OX1 3QY, UK; ariell.ahearn-ligham@ouce.ox.ac.uk (A.A.); fiona.mcconnell@ouce.ox.ac.uk (F.M.)

* Correspondence: troy.sternberg@geog.ox.ac.uk; Tel.: +44-(0)-186-528-5070

Received: 24 July 2017; Accepted: 18 August 2017; Published: 23 August 2017

\begin{abstract}
China's $\$ 1$ trillion One Belt, One Road (OBOR) infrastructure project has significant landscape, socio-economic, and political implications in recipient countries. To date, investigation has focused on Chinese motivation and plans rather than OBOR impact in host nations. This paper examines the programme from the perspective of two Central Asian states-Kazakhstan and Kyrgyzstan-that are at the heart of OBOR. We identify geographical factors that constrain infrastructure, recognise geopolitical contestation between Russia and China, address historical and cultural factors, and consider issues of institutional capacity and marginality that may be impediments to China's initiative. The discussion then focuses on how OBOR may play out in Central Asian landscapes and suggests how to conceive and address the unprecedented transformation in the region's built environment. Critical issues are that OBOR has not been grounded in the physical geography, practical understanding of OBOR's impacts is missing, and the state-citizen-China nexus remains unexplored. As pivot nations, OBOR implementation in Kazakhstan and Kyrgyzstan will showcase the Chinese programme's strengths and highlight its weaknesses.
\end{abstract}

Keywords: Central Asia; landscape; One Belt; One Road; Kazakhstan; Kyrgyzstan; infrastructure; environment; New Silk Road

\section{Introduction}

The world's first $\$ 1$ trillion infrastructure project has captivated global attention for its boldness, breadth, and transformative potential [1]. Presented as the New Silk Road, China's reach across Asia and beyond has no modern-day precedent. In May 2017, China's President Xi Jinping announced his 'One Belt, One Road' (OBOR) model to the world [2]. International attention has been focused on rail journeys from China to London, roads and pipelines across Asia, and rapid development trajectories. In China, the programme is presented as "a great undertaking that will benefit peoples around the world" [3] (p. 93). This mega-investment and infrastructure programme will have significant impact on the nations through which it traverses [4-6]. In the rush to construction, questions of sovereignty, cost, and obligations are yet to be resolved in recipient countries. Here we examine how building a silk road supernova resonates in two neighbouring nations at its Central Asian heart: Kazakhstan and Kyrgyzstan. Located on China's western border, they are pivot countries: how these states act and react will determine if the road paves a golden future or crumbles into a dusty dream.

OBOR is also known as Belt and Road Initiative (BRI), the Silk Road Economic Belt (SREB), and colloquially as the New Silk Road; use of OBOR in this paper reflects the most common and best-known acronym. A component programme is the Maritime Silk Road Initiative (MSRI) that expands China's interaction and investment throughout Southeast Asia, the Indian Ocean, and Arabian Sea through the Mediterranean to Europe [7]. In tandem, the land bridge and sea route comprise a grand vision of One 
Belt, One Road that encompasses multiple economic and political aims across dozens of countries [8]. Narratives in the expanding literature on OBOR consider Chinese motivations, strategic implications, economic integration, and geopolitical forces $[5,6,9,10]$. Recent scholarship is starting to conceptualise the programme through a range of theoretical lenses, yet has limited detail or regional and national specificity [7]. Parsing meaning at state and sub-national levels in recipient countries has yet to feature; nor do narratives engage with the role that physical environments through which OBOR travels will have. This paper examines the overland Belt and Road Initiative from the perspective of two Central Asian 'frontier states' (from China's viewpoint) and differentiates Kazakh and Kyrgyz roles and abilities to shape or benefit from OBOR. Further, we identify geographical factors that constrain infrastructure, recognise geopolitical contestation between Russia and China, address historical and cultural factors, and consider issues of institutional capacity and marginality that may be impediments to China's OBOR.

Whilst the emergent discussion of OBOR presents a policy, economic, and international relations perspective on the programme [5-7], the lack of engagement with landscapes for the world's largest infrastructure programme is striking. As OBOR aims to cross the Himalaya, Pamir, and Tien Shan mountains, traverse the deserts and steppe of Central, South, and Southwest Asia, and pass through active conflict zones (notably Afghanistan), overcoming geography, culture, and sparse resources (think water or food) will be a major challenge and consume much time and resources. Creating infrastructure involves residents, communities, governments, and physical embodiments of the nation state; thus, how land and society interact with an expansive foreign hegemon is an essential research focus. Integrating notions of land and geography, this paper evaluates how OBOR may play out in Kazakhstan and Kyrgyzstan. We examine the limited body of literature on OBOR that incorporates Central Asia (see [5,11-13]), tease out specific Kazakh and Kyrgyz motivations and concerns within this assessment (see [14-16] and introduce an applied geography view to consider the implications when 'earth and infrastructure' meet [17] (p. 2). The paper first contextualises OBOR in Central Asia and then considers regional geo-politics and geo-economics. Next, the physical landscape and infrastructure are examined and relevant social forces highlighted. The discussion then focuses on how OBOR may play out in Central Asia and suggests how the paper's original research idea can address an unprecedented transformation in the region's built environment.

\section{Contextualising OBOR in Central Asia: Regional Histories, Geopolitics, and Geoeconomics}

Chinese presentation of OBOR is as an idea or theme for engagement and development rather than a firm plan or roadmap [6]. Whilst OBOR details are elusive to outsiders, from the Chinese perspective it is 'an abstract and metaphorical concept' with the ancient silk road as a touchstone [18] (p. 2). This obscures the realpolitik of the programme that is President Xi Jinping's 'one and only major foreign policy initiative' [6] (p. 4). Any major transnational infrastructure programme is laden with expectation and liabilities; one country's outreach and expansion is another's incursion and obligation. Perhaps the two sides find a shared space of differentiated but positive benefit for both; for that to happen requires clarity of intent, roles, politics, and economic versus social benefits for giver and receiver at the outset. Cooley [5] presents the New Silk Road as a contest between 'traders' — development and economic interests - versus 'gamers' that see geopolitical angles as primary. Sidaway and Woon [4] (p. 4) assimilate this to suggest OBOR is a 'geopolitical strategy, albeit dependent and anchored on economic rationale'. China's intentional ambiguity [9] feeds a 'net gain' approach as opposed to a more benign regional development and soft power effort [19]. Other interpretations of the motivations underpinning OBOR abound (Table 1), from it being a project to absorb excess Chinese labour and capacity to the internationalisation of the yuan $[19,20]$. Whatever socio-political paradigm is intended or dominates, the impact will be most directly felt in its immediate neighbours that control the gateway to the west-Kazakhstan and Kyrgyzstan.

Central Asia is the historic core of silk roads through time [21-25]. It is here that Alexander the Great died in his quest for empire; where Marco Polo searched for silk routes to Venice, and 
Britain and Russia contested the Great Game that contributed to regional isolation [26]. Past silk roads between China and empires to the west presented Central Asia as 'mere transit stations' along the route [27] (p. 433). A century ago a British geographer and politician [28] identified Central Asia as the geographical 'pivot' of history, which all great land empires must control. This enduring saga is germane today, for this is where geography framed the past and economics aims to determine the future [29]. The Dzungarian Gate on the China-Kazakh border and the Torugart pass from Kashgar to Naryn, Kyrgyzstan are two of the few openings in the Tien Shan and Pamir mountains that allow past and present trade caravans to flourish (see Figure 1). Before China can access European markets overland, before goods can flow to West Asia and the Mediterranean and resources return to China, Kazakhstan and Kyrgyzstan must be crossed.

Table 1. Motivating factors for One Belt, One Road.

\begin{tabular}{cc}
\hline Reason & Citation \\
\hline Internationalisation of the Yuan & Chatham House (2017) [20] \\
Infrastructure development in Asia & Lim 2016 [6] \\
Consume overproduction, overcapacity, excess products & Lim 2016 [6] \\
Reduce unskilled unemployment in China & Tang 2015 [30] \\
Improve regional transport links & Lain and Pantucci 2015 [29] \\
Gain access to natural resources, oil, gas & Tang 2015 [30] \\
Increase Chinese soft power and good will & Sidaway and Woon 2017 [4] \\
Foreign policy initiative & Lim 2016 [6] \\
Sino-centric unipolar Asia & Malik in Sulekha 2017 [31] \\
Road to empire & Financial Times 2015 [32] \\
Benefits of development and prosperity & Sidaway \& Woon 2017 [4] \\
Enhance Chinese social stability and security & Rolland 2017 [3] \\
Integrate Eurasian continent by 2050 & Rolland 2017 [3] \\
Central Asia as "key areas" for China's national energy security & Rolland 2017 [3] \\
\hline
\end{tabular}

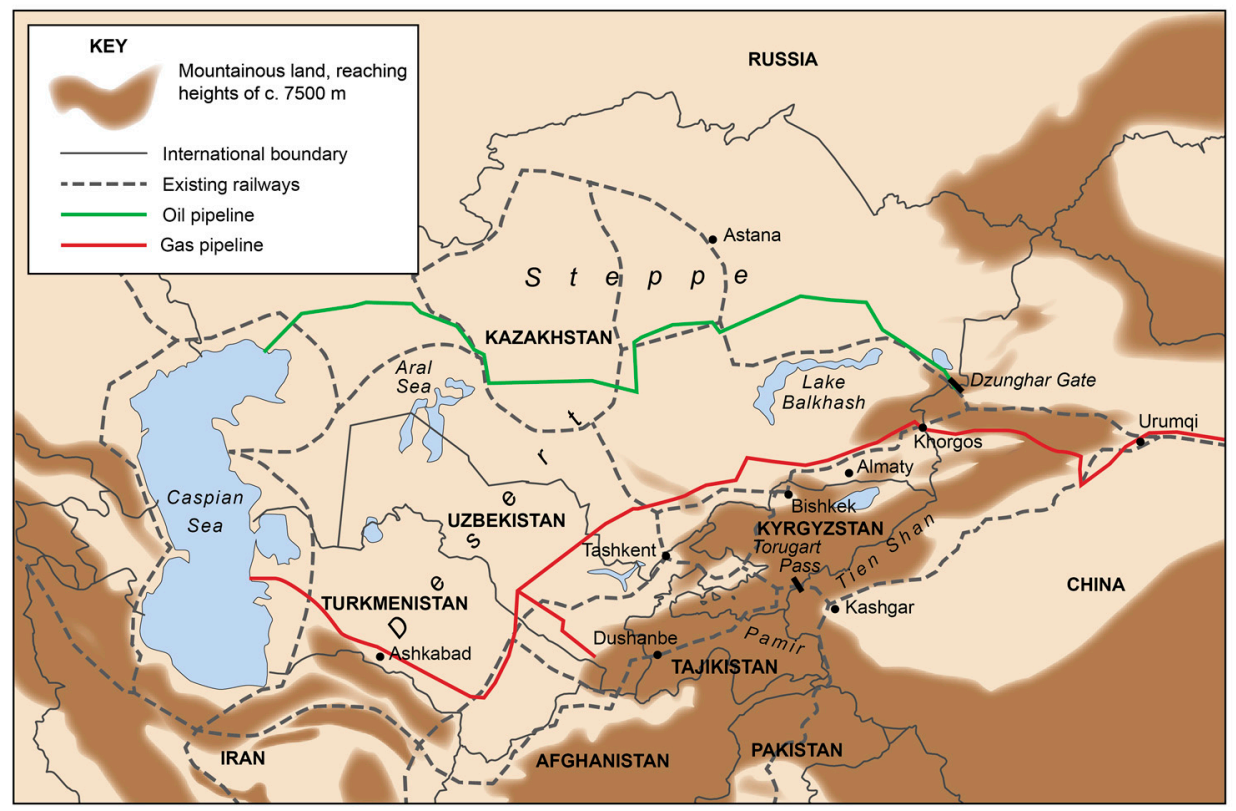

Figure 1. Map of Central Asia with geographical features (mountains, desert, steppe) and existing major infrastructure (pipelines, railroads).

Based on their histories, politics and socio-cultural contexts, Central Asian states have their own distinctive interpretations of what a New Silk Road means [7]. Location makes Kazakhstan and 
Kyrgyzstan the two key Central Asian players, though the countries have vastly divergent interests and needs. Kazakhstan presents an autocratic, rentier state that has extensive trade links and higher per capita income than China (\$12,436 vs. \$7616) [11,33]. Driven by energy resources and pipelines to western China, Kazakhstan can self-fund and self-direct infrastructure and development if desired; its energy hub is centred in the Caspian basin and is thus closer to Europe than China. Kyrgyzstan, with its struggling democracy, low living standard (\$1267 GDP per capita) and mountainous terrain has limited economic resources; already $50 \%$ of its national debt is owed to China. Both nations fear Chinese stealth encroachment through OBOR, with hints at new 'fangs of imperialism' [31] (p. 1). At the same time, both states are members of the Russia-driven Eurasian Economic Commission (EEU) that cedes significant trade rights and favours political deference to Russia. This drives a bifurcation between two spheres, as economics and development is dominated by China [13], yet must exist within Russian military, social, and political hegemony. In fact, the term 'New Silk Road' first appeared in 2011 as a US State Department initiative for 'new North-South transit and trade routes that complement vibrant East-West connections across Eurasia' ([34] (p. 1); [35]). The American initiative built on past Soviet economic flows through Central Asia. Announced by the US State Department as part of its exit strategy from Afghanistan, its aim was to re-integrate the country into traditional trading routes. Though conceptual frameworks have varied, the initiative's key points appear to presage and to have become core elements of China's nearly identical 2015 OBOR outline (Table 2) [9].

Table 2. New Silk Road Initiatives.

\begin{tabular}{cccc}
\hline 2011 & US-New Silk Road Initiative & 2015 & China-New Silk Road * $^{*}$ \\
\hline 1 & Regional energy markets & 1 & $\begin{array}{c}\text { Connectivity-infrastructure, logistics } \\
\text { energy, communication }\end{array}$ \\
2 & Trade and Transport & & Trade and customs \\
3 & Customs and border operations & 2 & Financial integration \\
4 & Businesses and people-to-people & 3 & People to people bond \\
& & 4 & Policy coordination \\
\hline
\end{tabular}

* Document officially titled Visions and Actions on Jointly Building Silk Road Economic Belt and twenty-first century Maritime Silk Road [36].

With such a major infrastructure programme come a suite of ancillary factors that are influenced by domestic circumstances in host nations. These include indirect OBOR implications from reshaping border zones (e.g., Khorgos Special Economic Zone, Kazakhstan), state capacity to direct, absorb, and monitor projects, and manifestations of marginality (social, economic, ecological, political) to ethnic contestation, (dis)integration along transport routes, and engagement and benefit from OBOR at community levels $[14,37]$. The uncertainty and potential direction of OBOR implementation is reflected in the $\$ 46$ billion Chinese-Pakistan Economic Corridor (CPEC) where the programme is most advanced [3]. The infrastructure crosses the Himalayas to Gwadar port on the Indian Ocean and involves tens of thousands of Chinese workers. Less direct are the routing of the pipeline and transport links within Pakistan, interaction with local populations, ethnic unrest, implications for fragile state institutions, and perceptions of benefit or exclusion. Issues of security and surveillance, rights of residents, water and environmental degradation, and wielding of de facto supra-state power raise questions about levers of control and for who's benefit is OBOR designed [38]. Resultant political infighting, grasping for infrastructure, volta face in nationalistic policy, and weak monitoring institutions point to the disruption major external infrastructure projects can have. Similar complexities can be expected as OBOR expands into Central Asia.

With an $\$ 8$ trillion Asian infrastructure deficit, China's 'most significant and far reaching project ... ever' expects to find receptive hosts in need of what may be on offer [5] (p. 11). Yet in traversing a region, economic and political forces become entwined with realpolitik. The five post-Soviet Central Asian states are caught in a bind: they must reconcile Russia's historic role with China's expanding economic dominance [35]. Participation in OBOR may not be centred on 
local interest and consent as much as acceptance of projects sanctioned by the regional hegemons. Thus, Russia will favour train lines through Kazakhstan that bring it goods and tariffs over tracks to the Caspian Sea that benefit China or Europe instead [12]. With funding directed by China, benefits will accrue through opening new markets for goods, procuring resources, and increasing access and engagement in previously underserved areas. Presented as an economic corridor, an OBOR of pipelines, bridges, roads, etc. is imagined for Central Asia to enhance security and energy cooperation [4]. The concurrent launch of the Asian Infrastructure Investment Bank (AIIB) provides both a funding source and implied international backing for large scale building projects.

Whilst OBOR, BRI, and the New Silk Road are all about China [39], frontier states are not a vacuum waiting to be filled or controlled [7]. A large part of any regional infrastructure programme goes through former Soviet territory that remains Russia's near-abroad today. This geopolitical background has created a convoluted ménage a trois between China, Russia, and comparatively weak Central Asian states [35]. Russia combines its roles as former (and aspiring) political overlord, military guarantor of (or perhaps threat to) sovereignty, trade partner through the Eurasian Economic Union (EEU), and cultural (particularly language, alphabet (Cyrillic vs. Latin) and media) touchstone with its former republics $[10,40]$. Though there are existing tripartite relations through the ongoing Shanghai Cooperation Organisation security alliance, the supercedent EEU dominates structural interaction between Russia and Central Asian states without China's participation [41]. Separate from Russian-Chinese relations, the EEU sets out a protocol that Kyrgyzstan and Kazakhstan follow for multi-faceted relations with trade benefits and restrictions within which China-Central Asian relations must be balanced. Thus, the two states are situated between two superpowers with different agendas. This is most notable in economics, where Central Asian trade with China increased from $\$ 1$ billion in 2002 to $\$ 45$ billion in 2014 [42]. The political and economic divergence leaves these states facing two masters with different remits and agendas, and potentially conflicting rather than co-existing interests. Russian self-interest will favour infrastructure that will be beneficial through trade, resources, and transit fees [12]. Reflecting this dichotomy, both countries export more to Russia than China, yet China is the largest source of imports. The unequal stature of the two key states finds that $>80 \%$ of China's regional trade is with Kazakhstan; benefits will thus accrue to Kazakhstan with limited support for disadvantaged Kyrgyzstan. Further, ethnic clashes have soured relations between Kyrgyzstan and Uzbekistan [43,44] with implications for China's envisioned shared projects (pipelines, railroads) through the Fergana Valley and onward to Afghanistan, Iran, and West Asia.

China has been instrumental in Kyrgyzstan's meagre development efforts whilst Russia maintains a military base. Vast amounts of new infrastructure is needed to replace aging and obsolete Soviet power plants, roads, bridges, dams, and hydro-electric power in Kyrgyzstan [45]. Yet the value of infrastructure-build for China in the country is not clear. Kyrgyzstan is central to the key planned rail route from Kashgar through Naryn and on to Uzbekistan [46], though currently China finds faster access traversing through Kazakhstan to Xinjiang Province. Such structural issues may limit and prescribe benefits to Kyrgyzstan. An unmentioned part of transport development in Kyrgyzstan is that its most valuable transit commodity is not minerals or oil but drugs. The state is on the main heroin route from Afghanistan to Europe through Kazakhstan and Russia where 25\% of the supply is transported [47]. Any expansion of roads without concomitant increased drug interdiction will potentially facilitate criminal activity and trafficking, including to China's eastern heartland. Infrastructure also represents possible links between ethnic groups separated by borders, facilitates transnational networks, and represents pathways for migrants. For example, China claimed Uighur separatists were responsible for the 30 August 2016 car bomb attack on the Chinese Embassy in Bishkek, Kyrgyzstan [48].

In sum, OBOR is a project writ large with myriad intentions and possible implications. At the macro-scale, it is a presentation of China to the world in the 21st century. A Chinese government perspective stresses 'development and prosperity', that OBOR 'is not a tool of geopolitics' and 'growing power and investments should not be seen as threatening' [4] (p. 3). What is written on 
OBOR is reflective of foreign perceptions of China's global engagement; circumspect articles decipher signals framed by external expectations and power relations vis-à-vis China. What is missing is the transition in thought to what OBOR tentacles may look like and engender on the ground in receiving nations. Existing narratives present OBOR as China's coming out event; now an interpretation and understanding of what this means for frontier states and host nations is imperative. As receivers of action, investment, and infrastructure, states are exposed to direct (physical, economic) and ancillary (social, environmental, political) benefits and costs.

Central Asia is largely overlooked in existing literature on OBOR, which has thus far largely attended to Chinese narratives about the initiative ([4], the Maritime Silk Road component (e.g., [7]), Chinese economic and political expansion in South East Asia [49], and the China-Pakistan Economic Corridor [3]. Research by Central Asian scholars and specialists has begun to turn attention to the potential impacts of OBOR in the region, focusing on narratives of state ideologies and development [13,16,43], the inability of Central Asian states to exert sovereignty [15], marginal borderlands [1,50], and expanding Chinese influence in the region [5,12]. These themes are important for OBOR, as they address the capacity of Kyrgyzstan and Kazakhstan to engage and absorb major infrastructure projects, and the existing literature suggests constraints and mixed outcomes. For example, ref. [10] (p. 376) views the New Silk Road as a series of mobilities through Central Asia that are corridors for 'hydrocarbons ... migrants ... drugs ... trade ... and military', a process matched by borders, immobility, and competition. Meanwhile, Reeves [50] examines how infrastructure brings hope as well as roads and questions territorial integrity. The varied discourses highlighted in this scholarship stresses Central Asian limitations in institutional capacity [51], environmental governance [52], and interaction with China [3] that are integral to a discussion on OBOR. Though land degradation and water stress are documented in the region $[53,54]$, connections between landscape, infrastructure, and land use, critical to OBOR implementation, have not been investigated. In the remainder of this paper we seek to sketch out what such a research agenda might look like.

\section{OBOR in Central Asia: Landscape, Infrastructure, and Socio-Political Dynamics}

\subsection{The Role of Landscape}

Infrastructure does not exist in a vacuum; it is a very land-based, physical undertaking that conforms to or manipulates an environment. The connection between 'earth and infrastructure exhibits a series of temporalities' [17] (p. 2). Geography matters; altitude, temperature, climate, people, and governance all affect infrastructure projects. Without context roads are ephemeral and unrealised and if built may not be fit for purpose. As conceived, the New Silk Road transects landscapes to connect places, transit goods, and peoples and spread interaction. OBOR implementation places Central Asian geography at the crux of any Chinese westward endeavour (Figure 1); physical factors contrive against expansion from China's heartland within the Great Wall. The Tibetan Plateau and Himalayas obstruct southwestern routes, concentrating CPEC's efforts on the Karakoram Highway. At $4693 \mathrm{~m}$, the Khunjerab Pass makes a treacherous choke point for roads, pipelines, and railroads making the long journey from Gwadar, Pakistan to Chinese territory. To the west, the Pamir and Tien Shan mountains are no less daunting; Peak Somoni (aka Stalin or Communism Peak) at $7495 \mathrm{~m}$, Sina Peak (aka Lenin Peak) at $7134 \mathrm{~m}$, and Kongur Tagh at $7649 \mathrm{~m}$ block physical access. To the north are the $2800 \mathrm{~km}$-long Tien Shans featuring Jengish Chokusu (aka Victory Peak) at $7439 \mathrm{~m}$ and Khan Tengri (aka Lord of the Spirits) at $7010 \mathrm{~m}$; they are breached by the Torugart Pass, at $3752 \mathrm{~m}$, that enables transit between Kashgar in Xinjiang and Naryn on the Kyrgyz high plateau (see Figure 1).

To the north, the Dzungarian Gate is the geographical and historical mountain pass between China and Kazakhstan, described as the 'one and only gateway in the mountain-wall which stretches from Manchuria to Afghanistan' [55,56] (p. 266). Through the gate flows oil and gas pipelines, China Highway 312, the train to Europe, and Chinese workers to make OBOR come to life in the near 
abroad. Now on the Kazakh side Khorgos is being developed as a Special Economic Zone and logistics hub for trade with China and set to be the primary OBOR portal within the decade [10].

Physical geography adds complexity to infrastructure, and may catalyse in unexpected events and 'provoke social and political crises that may not be contained' [17] (p. 2). Land is but the obvious barrier between two regions. With great mountains come severe cold, glacial landforms, low precipitation, temperature extremes, high winds, and solid rock barriers that not only impede and isolate the region but can thwart and crush infrastructure (Table 3). This is married to barren desert landscapes, little water, and poor agricultural productivity [53]. Natural disasters are a further threat to infrastructure, as Almaty, the largest city in the region (1.7 m inhabitants), is on a series of fault lines radiating out from the Tien Shan Mountains. The city was destroyed in a 1911 earthquake when shocks reached Kyrgyzstan; it is at high risk for another quake [57]. Central Asia's 'appalling record of water management' due to unsustainable use, dysfunctional systems, and poor cooperation among states suggests that the potential economic benefits come with high environmental costs and barriers [52] (p. 976).

Table 3. Physical factors in Central Asia.

\begin{tabular}{ccc}
\hline Factor & Kyrgyzstan & Kazakhstan \\
\hline Border with China, km & 1063 & 1765 \\
Elevation in metres, mean & 2988 & 387 \\
Temperature, annual mean & 5 & 2.2 \\
Precipitation, annual mean & 375 & 275 \\
Deserts, \% & 10 & $>80$ \\
Arable land, \% & 6.7 & 8.9 \\
Agriculture, \% of water & 93 & 66 \\
Population density, km ${ }^{2}$ & 27 & 6 \\
\hline
\end{tabular}

Environmental management has become a contentious issue in Central Asia as former Soviet comrades have become independent, and interdependent, nations where water is linked to energy and security [54]. Concurrently, increasing land degradation, driven by unsustainable irrigation and farming practices and overgrazing, directly impacts land and livestock productivity, incomes, and rural livelihoods [58]. Soil and water erosion, salinization, pollutants, and poor land management have contributed to $>60 \%$ of Kazakhstan and Kyrgyzstan's land identified as degraded and possibly desertified [53]. Land and water systems are based on Soviet structures, are not designed for transboundary cooperation, and are aggravated by historical legacies [58]. Existing land issues are exacerbated by China's interest in such resources, land-take for infrastructure, and increased bi-lateral assistance $[53,54]$. The transboundary nature of water adds complexity-Kyrgyzstan is water-rich yet infrastructure poor, Kazakhstan needs more water for agriculture, whilst China has plans to build dams in these states to harness hydropower. Further, climate variability and hazard risk are reflected in recent regional drought as harvest reduction, increased prices, and food insecurity reflect the fragility of land systems in the area [59]. Opaqueness in Chinese procurement of resource rights in the region points to contestation over land and water between current rural users and state-driven contracts. Acknowledgement and integration of environmental limitations within OBOR construction objectives is vital to minimise confrontation in this conflict-prone region [54].

\subsection{The Politics of Infrastructure}

The region's physical geography and geopolitical history both have significant influence on the existing and possible future infrastructure developments. Central Asia's Soviet-era railway gauge is $1.52 \mathrm{~m}$ whereas Chinese train track width is $1.435 \mathrm{~m}$. Thus, no direct train transport can take place; all train cars need to have the undercarriage physically changed to wide-gauge supporting bogies (wheel framework). Customs processing into Central Asia is the least efficient and most 
time consuming in the world; goods take up to 79 days to clear the border [5]. This points to rent seeking behaviour, inefficient government, and lack of interest or motivation to work effectively with neighbours. In fact, if days/weeks/months are lost in customs the point of OBOR-increased connectivity and time savings_-are negated and goods will continue to go by sea. Assessment by Cooley [5] identifies that Chinese officials expect 30\% of investment to be lost to corruption in Central Asia and $80 \%$ lost in Pakistan. This does not include the layers of guanxi (connections) that filter through projects originating in China [19].

The list of infrastructure projects intended for Central Asia under OBOR is unclear; previous investment has stressed pipelines, refineries, highways, and power plants (Tables 4 and 5). Any such list has two component parts: what China wants to build, and what the countries want to have built. The decision-making process is opaque, leaving the project drivers unidentified. Here, Kazakhstan and Kyrgyzstan need to be differentiated; the former wants infrastructure that compliments exports and energy integration with minimal disturbance to society [11]. The latter needs roads and railroads, better energy supply, and jobs for its people (>one million Kyrgyz (16\%) work in Russia) [60]. Both want benefits with an invisible, or moderated, Chinese presence due to distrust of Chinese intentions and perceived economic hegemony and land grabs by China [9]. Sinophobia pervades the region, perhaps inflamed by pervasive Russian media [14,61]. Can these differences be reconciled? One drawback of China's current 'all things to all people' stage is that there is no blueprint or document stating China's aims, standards, code of conduct, and treatment of local interests and sensitivities. Without a minimum framework trust remains low and arrangements are between states without community buy-in. In 2016, protests forced autocratic Kazakhstan to withdraw a law allowing foreigners to lease land in what was perceived as an imperial $\$ 1.9$ billion Chinese grab for agricultural lands and an implied stranglehold on food production [62].

Table 4. Chinese investments in Central Asia.

\begin{tabular}{clcc}
\hline Country & \multicolumn{1}{c}{ Project } & Cost-US \$ & Year Signed/Implemented \\
\hline Kazakhstan & Zhongfu Investment Group into oilseed processing & $\$ 1.2$ billion & 2016 \\
Kazakhstan & MangistauMunaiGas (50\%) & $\$ 2.6$ billion & 2009 \\
Kazakhstan & Kazakh portion-Central Asia-China gas pipeline & $\$ 6.7$ billion & 2009 \\
Kazakhstan & Ekibastuz GRES-2 Power Plant & $\$ 400$ billion & 2016 \\
Kazakhstan & Kazakhstan-China Oil Pipeline & $\$ 3$ billion & 2006 \\
Kyrgyzstan & Zhongda Oil Refinery & $\$ 430$ million & 2013 \\
Kyrgyzstan & Kyrgyz portion-Turkmenistan-China gas pipeline & $\$ 1.4$ billion & 2016 \\
Kyrgyzstan & North-South Highway & $\$ 400$ million & 2013 \\
Kyrgyzstan & Thermal power plant & \$386 million & 2014 \\
\hline & \multicolumn{2}{c}{ Tang/FMSO [30]; see additional references } \\
\hline
\end{tabular}

Table 5. Proposed One Belt, One Road (OBOR) investments.

\begin{tabular}{ccc}
\hline Country & Potential OBOR Investments & Project \\
\hline Kazakhstan & China-Central Asian pipeline & Natural gas \\
Kazakhstan & Eurasian Land bridge & Railway corridor \\
Kazakhstan & China-Central Asia-West Asia corridor & China to Iran rail link \\
Kazakhstan & Khorgos-Aktau railway & Caspian to China link \\
Kyrgyzstan & China-Kyrgyzstan-Uzbekistan railway & High-speed rail \\
\hline & & Cooley [5] 2016 \\
\hline
\end{tabular}

That such a turn of events happened in Kazakhstan bodes poorly for Chinese endeavours in Kyrgyzstan, Central Asia's most democratic-leaning state. Dissatisfaction with an ineffective government, elections, voting on regional and ethnic lines, and enduring poverty contribute to Kyrgyz discontent. State instability, intercommunal violence, a lack of jobs, and corruption continue to unsettle the country [44]. Since 2005 this has led to a series of 'Tulip Revolutions' through to street protests in 
2017 [63]. Having borrowed heavily from China, 38\% of its $\$ 3.7$ billion external debt is to China's ExIm Bank alone [45]. For example, the $\$ 390$ million Datka-Kemin north-south power line and $\$ 400$ million north-south road are part of the existing Chinese debt package [13], highlighting how decisions against China's wishes may become problematic. What Kyrgyzstan most wants-jobs-are the very thing that Chinese infrastructure projects do not provide. Instead, Chinese labourers are brought in by the (tens of) thousands, as Pakistan's CPEC experience shows [38].

Discussions in Central Asia with civil society and academics stress the high awareness of OBOR and equally the lack of clarity and uncertainty about intent, timeframe, and expected outcomes. The local perspective focuses on what will be imposed without apparent consultation or meaning for communities. In Kyrgyzstan, past examples and a perceived influx of Chinese create a negative perception of what OBOR will mean domestically. Comments on a railway from Kashgar to Uzbekistan drily note few Kyrgyz will be on the train, as it will not pass through Bishkek. These observations reflect the work of Alff [14] (p. 440) on Kyrgyzstan as a Chinese 'vassal state'. Transport and potential subsequent development corridors are also viewed as aiding expansion of drug trafficking [10]. Kazakhstan is more favourable to OBOR, as the programme may increase exports and thus income. Infrastructure will be far removed from the business capital of Almaty, yet the mooted possible increased Chinese involvement in food production raises nationalistic concern. In both states the programme is perceived as externally directed with minimal domestic interaction.

To set some context for how OBOR is and will be received on the ground in Central Asia, it is important to note key socio-cultural dynamics in the region. Kyrgyz and Kazakhs are Turkic nationalities with shared linguistic, religious, and cultural roots from across what was once called Turkestan, a vast area stretching from the Tibetan Plateau and Himalayas to the Caspian Sea and Turkey. Identity, kinship, spiritual practices, and lifestyles remain vastly different from that of the Han Chinese. In the Soviet era, there was a massive influx of other ethnic groups into the region, including millions of Russians and significant numbers of Ukrainian, German, and Korean immigrants. More than 3.5 million Russians remain in Kazakhstan and Kyrgyzstan, further differentiating the people and orientation of the region from China. Today this contributes to separation and animosity between local residents and incoming Chinese with fear of de facto economic appropriation expressed in major cities [14,61]. Government to government relations are strong, but as 2016 protests of perceived Chinese land-grabs in Kazakhstan demonstrated, these may not be attuned to local sentiments [62]. Thus, as OBOR projects are initiated, citizen interest and acceptance needs to be considered and addressed.

This raises important subsidiary issues that come with mega-projects and investments. Are institutions, capacity, and expertise in place for consensual development programmes? Are adequate legal structures, customs unions, institutional oversight, and security measures set up to handle new flows and volume of goods and people? In a traditionally autocratic region, what role do citizens and communities have in recommending, shaping, and deciding on investments, locating routes, demarcating impact zones, and monitoring social and environmental impacts and liabilities? These currently unaddressed issues are key to OBOR's success. Without citizen engagement, economic relevance, and adequate planning, what happens once the concrete dries will remain an unknown. China's $\$ 430$ million Zhongda oil refinery in northern Kyrgyzstan exemplifies how quickly Chinese mega-projects can go awry. Only a fraction of the 850,000 ton annual capacity is being used, as China failed to secure crude oil supply before building the facility. The investor has asked for Russia's assistance; Russia does not have interest in supplying raw materials to new Chinese players in their near abroad [64]. Without better understanding of local context and rational business planning development in Central Asia risks becoming at best a muddled story or infrastructure folly, and at worst igniting regional tensions. Currently several major Chinese projects are scheduled for Central Asia spanning roads, railroads, airports, power plants, and dams (Table 5). Like the Zhongda refinery, they are grand investments that are presented with limited scrutiny and uncertain economic justification. The in-country decision-making process is not transparent and whether projects are requested by or aligned with local interests is not ascertained. In this way OBOR reads less a partnership of friends as 
cogs in a Chinese mega-development plan. Thus, how new works address and incorporate local needs is obfuscated by fait-accompli announcements and state relations.

The presentation of OBOR in Central Asia provides little evidence of planning for environmental impacts or engaging with residents. This may include project siting, adequate resources such as water for both the project build and ongoing functioning, and land degradation and rehabilitation [52]. Roles for local communities, jobs, livelihood changes, and security are unstated. Further, ancillary processes such as implications for culture, ethnicity, and migration are unaddressed. Sinophobia in Central Asia is well known and inhibits rational assessment of infrastructure projects, a process clouded by the lack of transparency and limited role for host communities [11,42]. The sentiment may in part be a response to inflammatory Chinese government comments such as that Central Asia was a "rich piece of cake given to today's Chinese people by heaven" [3] (p. 118). As one local Kyrgyz commented, 'first they started sending their goods, then they started moving in, and finally they marry our local women." [30] (p. 18).

Self-perception and socio-economic factors colour trade and thus OBOR relations with China. Autocratic Kazakhstan views itself as the Central Asian power and with a positive balance of trade (>\$38 billion annually) [33] is not dependent on China for physical development. This is reflected in Kazakhstan's trade surplus with China, a major buyer of the country's energy resources [65]. Conversely, Kyrgyzstan has few alternate methods to fund major infrastructure. Whilst the government encourages Chinese investment, citizens are not welcoming to China's expanded presence. As a struggling democracy, the Kyrgyz political class can in part attract voters by appearing to keep China at an arm's length. In the 2017 presidential elections, only a small number of candidates support OBOR in their campaign rhetoric.

Soft power themes ask if benefit will be accomplished through trans-cultural interaction or by receiving unreciprocated Chinese business and tourism. The term soft power implies a welcome, an invitation to exchange people, goods, ideas, and opportunity. Is this in the nature of a road or a pipeline? Or are the Chinese asking citizens to focus on second and third generation benefits delayed through oil contracts, debt payments, and rentier bureaucracies? The real possibility exists that China starts below zero on a soft power scale in Central Asia. Pantucci [61] identifies Sinophobia as the biggest regional problem that China faces with its Silk Road Economic Belt policy in Central Asia. This is nowhere in Silk Road plans and agendas. Without an OBOR charter of local principles or explanation of the Kazakh or Kygyz rights and responsibilities in a way that can be monitored and transform behaviour, residents have little justification to expect transparency or the prospect of participation in unfolding OBOR stories.

To reconcile the potential value of OBOR with its possible adverse consequences will take active acknowledgement of challenges and the engagement of principal players. Greater transparency in decision-making, clarity in project ownership and control, channels for local input and consultation, and a collaborative approach amongst diverse stakeholders is essential. The process would start with Chinese willingness to develop a Code of Conduct stating project rights and remedies-with governments informing citizens about OBOR plans and expectations and explanation of how communities are involved, geography accommodated, and monitoring enabled. Two mega-projects suggest ways forward: China National Petroleum Corp mentions Corporate Social Responsibility efforts in its report on Kazakhstan, suggesting nascent community awareness and a way to improved relations. The Kumtor Gold Mine in Kyrgyzstan (owned by Centerra of Canada) is embroiled in long-running disputes with the government over royalties and alleged environment damage. This may, in fact, be a positive process, as it reflects the impact of citizen protest in making infrastructure development accountable. Yet the lack of constructive mechanisms to resolve contested issues infers a tortuous development path awaits. Most OBOR interaction is stymied by perceived heavy-handed infrastructure-as-expansion, fissures between states and citizens, weakness of host nations vis-a-vis China, and an insensitive and overbearing Chinese agenda. Geographical challenges may have 
alternate routes, engineering solutions, or mitigation potential. As geo-political and social fractures solidify, discord may become both intractable and OBOR's major legacy.

\section{Uncertainty, National Differences, Marginality, and Sino-Centrism}

'Advancing westward was "a historical necessity for the Chinese nation, and it is also our destiny." ... Central Asia should thus be regarded "as territory to be recovered in our advance, not as a border region"' PLA General Liu Yazhou [3] (pp. 117-118).

A massive infrastructure programme, a major Chinese westward expansion, an offering of altruistic friendship, an example of manifest destiny-evaluation of OBOR offers a tabula rasa for Central Asia and the world. Interpretations abound yet facts are few on the ground. We stress four themes in the Central Asian context: uncertainty is an OBOR hallmark, events and infrastructure will play out differently in Kazakhstan and Kyrgyzstan, capacity and marginality will challenge infrastructure development, and ultimately all roads lead back to China (see [4]). A core tenet presented in the work of Barry [17] is that infrastructure is constructed on real geography through living communities, rather than in presidential speeches and grand edicts, is critical in a region of $7000+$ metre mountains, deserts, extreme climates, and different cultures. The 'physical' will meet the 'theoretical' in OBOR's march westward. As Peyrouse and Raballand [35] (p. 413) state, 'a route on a map ... does not create traffic and trade'.

Interrogation of the uncertain, muddled human dimensions will provide a more robust evaluation of a New Silk Road in Central Asia. This proffers questions about institutional transformation or subordination, external annexation or domestic-driven collaboration, and benefit defined at the mega, national, or personal scale. Issues of livelihood enhancement and increased human opportunity, environmental sustainability, community development, and economic improvement are yet to be scrutinised and integrated into the grand rhetoric. The human element exposes its darker side-marginalisation of citizens, lost or foregone opportunity and jobs, roads as pathways to migration and trafficking, a diminution of rural prospects and populations, concentration of benefit in urban hubs, and degradation of environmentally based lives as agriculture, pastoralism, and livestock raising are isolated by infrastructure or overtaken by markets manifest in land grabs. Is organic growth on offer or is this a coercive multi-state project lacking civic relevance or nation-bonding through sacrifice of public space and engagement?

Within Central Asian dynamics Kazakhstan is well-placed to profit from OBOR as it is both politically and economically close to Russia whilst a major oil exporter to China. Once over the Tien Shan Mountains geography favours infrastructure across the flat steppe and established rail routes link the three countries. Solid state finances offer Kazakhstan a buffer; it does not need OBOR for development or domestic (e.g., voting) exigencies. In comparison, Kyrgyzstan is mountain-bound, on the proposed train line to (unfriendly) Uzbekistan, without oil, and in need of what China may decide to offer. This weak hand gives little leverage for the country and few alternate development sources. Where Kazakhstan perceives itself as an equal in negotiation, Kyrgyzstan is an OBOR supplicant.

The idea of marginality runs through the rural territories that will host infrastructure. Such contexts are on the fringe of political and economic loci of control that initiate projects, are spatially isolated and often on the edge of borders, and are often further separated by poverty, social group, and livelihood opportunity. High speed rail and pipelines designed to circumvent locals may lack relevance and result in failed projects (such as the Zhonga refinery) or, opposite to development, promote further disintegration within fraying social-political contexts. Whilst citizens in Kazakhstan or Kyrgyzstan cannot derail OBOR, they can, and have, changed regimes in Kyrgyzstan and may again protest against the aging autocracy in Kazakhstan. If infrastructure becomes corridors without context, alters or degrades an environment, or segregates development trajectories the 'soft power' path will be missed whilst inequality, Sinophobia, and dispossession remain. As Diener [10] (p. 380) states, 'roads may separate as much as they connect'. The tantalising rewards of OBOR will come with a foundation that engages with national and local discourses. In coming years more can be done by 
OBOR proponents to identify standards and procedures that encourage domestic participation and acceptance rather than an external, top-down imposition of Chinese will on frontier states. This raises the spectre of nations' abilities to digest OBOR against a host of domestic factors from stability, ethnicity, and marginality to control and external influence.

Finally, procedures, announcements, efforts at persuasion, and maps show OBOR as a China-directed, optimistic, multi-faceted expansion effort (see Table 1). It is thus self-reflective-how can infrastructure benefit China and Chinese in state, business, employment, and citizen realms-reflected in General Liu's presumption of 'destiny'. Whilst the effort shows China going out into the world, in truth all roads lead back to China [39]. This is where benefit will be determined, success claimed, and new markets or resources conquered. Central Asia is the first stop on the parade. With small populations, malleable governments, and an inability to create and drive mega-projects, Kazakhstan and Kyrgyzstan are prime candidates to accommodate China's largess and attention. Success by flexible and undefined measures belongs to China. Failure of physical structure, economic profit, or citizen disapproval (even damage) will rest with the Central Asians. This is where grand integration meets with uncontrolled forces. These could be in the form of climate, earthquakes, droughts, famine, terrorism, conflict, or revolution-all have happened in Central Asia. Any of these can change Chinese hubris into humbleness as the New Silk Roads careen their way through Central Asia.

\section{Conclusions}

Tracking OBOR into Central Asia frames the possibilities and challenges the programme encounters in Kazakhstan and Kyrgyzstan. Historical, cultural, and economic factors separate the nations from China whilst development differentiates the two states. Borders and geography constrain infrastructure, superpower geopolitics impede state autonomy, corridors favour Chinese interests (resources, business) over local agendas, whilst OBOR objectives and outcomes in the region remain opaque [31]. Grounding the narrative identifies Central Asian characteristics that will ameliorate or mitigate the grand intentions of the New Silk Road.

Within OBOR several competing strands present themselves. Foremost are considerations regarding what is built and for whom. The implications of pipelines, roads, airports, etc. are tangible manifestations of Chinese prowess, development, and interstate collaboration. Secondary physical expressions-changes in water, land, and environment-are also part of OBOR. Less concrete but equally OBOR related are the suite of social, institutional, economic, and governance benefits and disruptions, with values assigned by perspective. To China, building infrastructure is a clear public good, a mantra often repeated in the Tibet and Xinjiang contexts. To Kazakhstan, infrastructure enabling trade and economic gain is positive; in Kyrgyzstan, any new construction is a boon, filling key gaps the state is unable to address. These macro-level representations extol the 'development and prosperity' the literature promises. These are the voices and vistas that will be shared for global consumption.

Given the scale, complexity, and inherent uncertainties regarding OBOR, identifying potential mechanisms for addressing challenges faced in Central Asian states is difficult if not unachievable. Based on our review of existing literature and analysis of geographical, social, and political contextual factors, the following key issues for further discussion emerge.

The lack of transparency regarding planned or proposed OBOR projects needs to be rectified. A first step would be ensuring that channels of communication are in place between Chinese planners/developers and Central Asian governments and, crucially, local communities that will be affected by the infrastructure developments.

Communication and coordination across China's 'frontier states', including Pakistan, where OBOR projects are more advanced (e.g., CPEC), can be facilitated and strengthened.

Clear OBOR objectives, standards, and rights should be established and expressed at local, state, and transnational levels. 
Whilst current research considers manifestations of OBOR in Central Asia, this paper identifies three critical research ideas for future investigation. First, OBOR has not been grounded in Central Asia's physical landscape. Understanding the infrastructure footprint can be done through fieldwork and remote sensing to capture land area sacrificed and demands on water, and land use vis-a-vis dependent communities; Second, improved knowledge of the practical implications of OBOR on rural residents, livelihoods, and communities presents a gaping hole in current project understanding. Third, the host state institutions-citizens-Chinese outreach nexus awaits exploration. In combination, these significant research themes will offer insight, astuteness, and realistic knowledge about China's infrastructure expansion into Central Asia.

Acknowledgments: The research was funded by the John Fell Fund, University of Oxford and encouraged by Oxford's School of Geography. The University of Central Asia, American University of Central Asia, KIMEP University, and Kazakh National University were supportive of research and the Aga Khan Development Network added perspective and insights. We thank anonymous reviewers for their recommendations that improved the manuscript.

Author Contributions: Troy Sternberg conceived, researched and wrote the paper; Ariell Ahearn and Fiona McConnell contributed research framing, ideas, context and wordsmithing.

Conflicts of Interest: The authors declare no conflict of interest.

\section{References}

1. NY Times behind China's $\$ 1$ Trillion Plan to Shake Up the Economic Order. 2017. Available online: https: //www.nytimes.com/2017/05/13/business/china-railway-one-belt-one-road-1-trillion-plan.html?_r=0 (accessed on 13 May 2017).

2. Xinhua. President Xi's Speech at Opening of Belt and Road Forum. 2017. Available online: news.xinhuanet. com/english/20USD17-05/14/c_136282982.htm (accessed on 14 May 2017).

3. Rolland, N. China's Eurasian Century? Political and Strategic Implications of the Belt and Road Initiative; NBR: Seattle, WA, USA, 2017.

4. Sidaway, J.; Woon, C. Chinese Narratives on "One Belt, One Road" in Geopolitical and Imperial Contexts. Prof. Geogr. 2017, 1-13. [CrossRef]

5. Cooley, A. The Emerging Political Economy of OBOR: The Challenges of Promoting Connectivity in Central Asia and Beyond. Center for Strategic and International Studies. Available online: www.csis.org/analysis/ emerging-political-economy-obor (accessed on 16 March 2017).

6. Lim, T.W.; Chan, H.H.; Tseng, K.H.; Lim, W.X. China's One Belt One Road Initiative; Imperial College Press: London, UK, 2016.

7. Blanchard, J.; Flint, C. The Geopolitics of China's Maritime Silk Road Initiative. Geopolitics 2017, 22, 223-245. [CrossRef]

8. Blanchard, J. Probing China's Twenty-First-Century Maritime Silk Road Initiative (MSRI): An Examination of MSRI Narratives. Geopolitics 2017, 22, 246-268. [CrossRef]

9. Summers, T. China's 'New Silk Roads': Sub-National regions and networks of global political economy. Third World Quart. 2017, 37, 1628-1643. [CrossRef]

10. Diener, A. Parsing mobilities in Central Eurasia: Border management and new Silk Roads. Eurasian Geogr. Econ. 2015, 56, 376-404. [CrossRef]

11. Kassenova, N. China's Silk Road and Kazakhstan's Bright Path: Linking Dreams of Prosperity. Asian Policy 2017, 24, 110-116. [CrossRef]

12. Pantucci, R.; Lain, S., III. The Plan: Infrastructure and Integration. Whitehall Pap. 2016, 88, 30-46. [CrossRef]

13. Toktomushev, K. Central Asia and the Silk Road Economic Belt. Policy Brief 2016-1. 2016. Available online: http:/ / ucentralasia.org/Resources/Item/1218 (accessed on 11 August 2017).

14. Alff, H. Flowing goods, hardening borders? China's commercial expansion into Kyrgyzstan re-examined. Eurasian Geogr. Econ. 2016, 57, 433-456. [CrossRef]

15. Doolot, A.; Heathershaw, J. State as resource, mediator and performer: Understanding the local and global politics of gold mining in Kyrgyzstan. Cent. Asian Sur. 2015, 34, 93-109. [CrossRef]

16. Sullivan, C. State-Building in the Steppe: Challenges to Kazakhstan's Modernizing Aspirations. Strateg. Anal. 2017, 41, 273-284. [CrossRef] 
17. Barry, A. Infrastructure and the Earth. In Infrastructure and Social Complexity; Harvey, P., Jensen, C., Morita, A., Eds.; Routledge: London, UK, 2016.

18. Liu, W. Yidai yilu zhanluede renshi wuqu [The misconceptions of One Belt, One Road]. Guojia Xingzheng Xueyuan Xuebao 2016, 1, 3-6.

19. Guluzian, C.R. Making Inroads: China's New Silk Road Initiative. Cato J. 2017, 37, 135.

20. Chatham House The 'Belt and Road' Initiative and the London Market-The Next Steps in Renminbi Internationalization Part 2: The View from London. 2017. Available online: https:/ / www.chathamhouse. $\mathrm{org} /$ publication/belt-and-road-initiative-and-london-market-next-steps-renminbi-internationalization (accessed on 14 March 2017).

21. Polo, M. Il Milione, 1827 version; Da'torchi de G Pagani: Firenze, Italy, 1298.

22. Von Humboldt, A. Asie Centrale, Recherches sur les Chaînes des Montagnes et la Climotologie Compare; Gide: Paris, France, 1843.

23. Hedin, S. Central Asia and Tibet: Towards the Holy City of Lassa; Hurst and Blackett: London, UK, 1908.

24. Thubron, C. The Lost Heart of Asia; Random House: London, UK, 2004.

25. Francopan, P. The Silk Roads: A New History of the World; Bloomsbury: London, UK, 2015.

26. Hopkirk, P. The Great Game: On Secret Service in High Asia; John Murray: London, UK, 1990.

27. Rezakhani, K. The Road That Never Was: The Silk Road and Trans-Eurasian Exchange. Comp. Stud. South Asia Afr. Middle East 2010, 30, 420-433. [CrossRef]

28. Mackinder, H.J. The geographical pivot of history. R. Geogr. Soc. 1904, 170, 298-321. [CrossRef]

29. Lain, S.; Pantucci, R. The Economics of the Silk Road Economic Belt. 2015. Available online: rusi. org / publication / conference-reports / economics-silk-road-economic-belt?page=4MarcoPolo (accessed on 11 February 2017).

30. Tang, D. China's Investment in the Central Asian Republics. Foreign Military Studies Office, 2015; Available online: https:/ $/$ www.google.co.uk/url?sa=t\&rct=j\&q=\&esrc=s\&source=web\&cd=1\& ved=0ahUKEwjRwvr61-nVAhXFAMAKHfFmBCwQFggyMAA\&url=https\%3A\%2F\%2Fcommunity. apan.org\%2Fwg\%2Ftradoc-g2\%2Ffmso\%2Fm\%2Ffmso-monographs\%2F194970\%2Fdownload\&usg= AFQjCNE3h189j-8w_5WlyhfCXhwYYL18ww (accessed on 18 May 2017).

31. Sulekha, R. Chinese Imperalism: OBOR_An Economic Mouse Trap! 2017. Available online: creative.sulekha. com/chinese-imperalism-obor-one-belt-one-road-an-economic-mouse-trap_632075_blog (accessed on 4 April 2017).

32. Financial Times. China's Great Game: Road to a New Empire. Available online: https:/ /www.ft.com/ content/6e098274-587a-11e5-a28b-50226830d644 (accessed on 5 April 2017).

33. United Nations. National Statistics. 2017. Available online: data.un.org (accessed on 16 May 2017).

34. US State Department. U.S. Support for the New Silk Road. 2015. Available online: https:/ /2009-2017.state. gov/p/sca/ci/af/newsilkroad/index.htm (accessed on 5 June 2017).

35. Peyrouse, S.; Raballand, G. Central Asia: The new Silk Road initiative's questionable economic rationality. Eurasian Geogr. Econ. 2015, 56, 405-420. [CrossRef]

36. Xinhua. Vision and Actions on Jointly Building Silk Road Economic Belt and Twenty-First Century Maritime Silk Road. 2015. Available online: news.xinhuanet.com/english/china/2015-03/28/c_134105858.htm (accessed on 16 May 2017).

37. Pelc, S. Marginality and Marginalization. In Societies, Social Inequalities and Marginalization; Chand, R., Nel, E., Pelc, S., Eds.; Springer: London, UK, 2017; pp. 13-28.

38. Dawn. CPEC Master Plan Revealed-Pakistan. 2017. Available online: www.dawn.com/news/1333101 (accessed on 18 May 2017).

39. Casarini, N. When All Roads Lead to Beijing. Assessing China's New Silk Road and its Implications for Europe. Int. Spect. 2016, 51, 95-108.

40. Laruelle, M. Russia and Central Asia. In The New Central Asia: The Regional Impact of International Actors; World Scientific: London, UK, 2010; pp. 149-176.

41. Karaganov, S.; Bordachev, T.; Barabanov, O.; Bezborodov, A.; Gabuev, A.; Kuzovkov, K.; Lukin, A.; Suslov, D.; Likhacheva, A.; Makarov, I.; et al. Creating Central Eurasia: The Silk Road Economic Belt and the Priorities of the Eurasian States' Joint Development. Russ. Stud. 2015, 3, 002.

42. Peyrouse, S. Discussing China: Sinophilia and Sinophobia in Central Asia. J. Eurasian Stud. 2016, 7, 14-23. [CrossRef] 
43. Gullette, D.; Heathershaw, J. The affective politics of sovereignty: Reflecting on the 2010 conflict in Kyrgyzstan. Natl. Pap. 2015, 43, 122-139. [CrossRef]

44. Megoran, N.; Satybaldieva, E.; Lewis, D.; Heathershaw, J. Peacebuilding and Reconciliation Projects in Southern Kyrgyzstan. Working Paper; Stockholm International Peace Research Institute/Open Society Foundation, 2014. Available online: www.sipri.org/sites/default/files/SIPRI-OSFno2WP.pdf (accessed on 13 June 2017).

45. EurasiaNet. Kyrgyzstan Reaches New Heights of Debt. 2016. Available online: www.eurasianet.org/node/ 79531 (accessed on 5 June 2016).

46. UK Foreign Office. The China-Kyrgyzstan-Uzbekistan Railway Project. 2014. Available online: https: //www.gov.uk/government/publications/the-china-kyrgyzstan-uzbekistan-railway-project (accessed on 4 June 2016).

47. Ramani, S. Kyrgyzstan's Risky Open Borders Experiment. Diplomat, 2015. Available online: thediplomat. com/2015/08/kyrgyzstans-risky-open-borders-experiment/ (accessed on 20 May 2017).

48. Clarke, M. China's Terrorist Problem Goes Global. The Diplomat, 2016. Available online: thediplomat.com/ 2016/09/ chinas-terrorist-problem-goes-global/ (accessed on 20 May 2017).

49. Soong, J. The Political Economy of Development between China and the ASEAN States: Opportunity and Challenge. Chin. Econ. 2016, 49, 395-399. [CrossRef]

50. Reeves, M. Infrastructural Hope: Anticipating 'Independent Roads' and Territorial Integrity in Southern Kyrgyzstan. Ethnos 2017, 82, 711-737. [CrossRef]

51. Heathershaw, J.; Cooley, A. Offshore Central Asia: An Introduction. Cent. Asian Surv. 2015, 34, 1-10. [CrossRef]

52. Howard, K.W.; Howard, K.K. The new "Silk Road Economic Belt" as a threat to the sustainable management of Central Asia's transboundary water resources. Environ. Earth Sci. 2016, 75, 1-12. [CrossRef]

53. Robinson, S. Land degradation in Central Asia: Evidence, perception and policy. In The End of Desertification? Behnke, R., Mortimore, M., Eds.; Springer: Berlin, Germany, 2016; pp. 451-490.

54. Abdolvand, B.; Mez, L.; Winter, K.; Mirsaeedi-Gloßner, S.; Schütt, B.; Rost, K.; Bar, J. The dimension of water in Central Asia: Security concerns and the long road of capacity building. Environ. Earth Sci. 2015, 73, 897-912. [CrossRef]

55. Carruthers, A.; Miller, J.H. Unknown Mongolia: A Record of Travel and Exploration in North-West Mongolia and Dzungaria; Hutchinson \& Company: London, UK, 1914; Volume 2.

56. MacFarquhar, R.; Fairbank, D.; Twichett, D. Cambridge History of China: The People's Republic, Part 2: Revolutions within the Chinese Revolution, 1966-1982; Cambridge University Press: Cambridge, UK, 1991.

57. ODI (Overseas Development Institute). Earthquake Science and Hazard in Central Asia. 2016. Available online: www.odi.org/sites/odi.org.uk/files/resource-documents/11151.pdf (accessed on 18 May 2017).

58. Mirzabaev, A.; Ahmed, M.; Werner, J.; Pender, J.; Louhaichi, M. Rangelands of Central Asia: Challenges and opportunities. J. Arid Land 2016, 8, 93-108. [CrossRef]

59. Granit, J.; Jägerskog, A.; Löfgren, R.; Bullock, A.; de Gooijer, G.; Pettigrew, S.; Lindström, A. Regional Water Intelligence Report Central Asia; SIWI: Stockholm, Sweden, 2010. Available online: watergovernance.org/ resources/regional-water-intelligence-report-central-asia/ (accessed on 18 May 2017).

60. IRIN. Hope and Fear: Kyrgyz Migrants in Russia. 2015. Available online: http:/ /www.irinnews.org/report/ 101398 /hope-and-fear-kyrgyz-migrants-russia (accessed on 24 June 2017).

61. Pantucci, R. Looking West: China and Central Asia. 2015. Available online: http:/ / chinaincentralasia.com/ 2015/04/16/looking-west-china-and-central-asia/ (accessed on 16 March 2017).

62. Farchy, J. China Plans to Invest $\$ 1.9$ bn in Kazakh Agriculture. 2017. Available online: www.ft.com/content/ 9c84a0f4-15d3-11e6-9d98-00386a18e39d (accessed on 27 May 2017).

63. Putz, K. After Opposition Leader Is Detained, Protests Kick off in Kyrgyzstan. The Diplomat, 2017. Available online: thediplomat.com/2017/02/after-opposition-leader-is-detained-protests-kick-off-in-kyrgyzstan/ (accessed on 4 June 2017). 
64. Rickleton, C. Kyrgyzstan: Chinese Investor Struggling without Russian Help. 2015. Available online: www.eurasianet.org/node/71776 (accessed on 7 May 2017).

65. Trading Economics Kazakhstan Balance of Trade. 2017. Available online: www.tradingeconomics.com/ kazakhstan/balance-of-trade (accessed on 24 May 2017).

(c) 2017 by the authors. Licensee MDPI, Basel, Switzerland. This article is an open access article distributed under the terms and conditions of the Creative Commons Attribution (CC BY) license (http:/ / creativecommons.org/licenses/by/4.0/). 